$$
\begin{aligned}
& \Delta \mathrm{d} \alpha=\beta_{0}\left(\frac{\cos \varphi}{\cos \delta} \cdot \frac{\sin \nu \sin (\mu+\delta)}{\sin ^{2} n \sin ^{2}(m+\delta)} \mathrm{d} \alpha+\frac{\cot n \cos (m+2 \delta)}{\cos ^{2} \delta \sin ^{2}(m+\delta)} \mathrm{d} \delta\right), \\
& \Delta \mathrm{d} \delta=\beta_{0}\left(\frac{\cos \varphi \cos \nu}{\sin ^{2} n \sin ^{2}(m+\delta)} \mathrm{d} \alpha+\frac{\mathrm{I}}{\sin ^{2}(m+\delta)} \mathrm{d} \delta\right),
\end{aligned}
$$

in which

$$
\begin{array}{ll}
\tan m=\cot \varphi \cos (\theta-\alpha), & \cot \mu=\tan \varphi \cos (\theta-\alpha), \\
\cot n=\sin m \tan (\theta-\alpha), & \cot \nu=\cos \mu \tan (\theta-\alpha) .
\end{array}
$$

Dunsink Observatory 1892 Sept. 8.

Arthur A. Rambaut.

\title{
An account of the discovery of a fifth satellite to Jupiter.
}

(Auszug aus einer Mittheilung von Prof. E. E. Barnard in Astronomy and Astrophysics«, October r 892 .)

... Friday [Sept. 9] being my night with the 36 inch telescope, after observing Mars and measuring the positions of his satellites, I began an examination of the region immediately about the planet Jupiter. At 12 o'clock as near as may be, to within a few minutes, I detected a tiny point of light close following the planet and near the $3^{\mathrm{a}}$ satellite which was approaching transit. I immediately suspected it was an unknown satellite and at once began measuring its position angle and distance from the $3^{\mathrm{d}}$ satellite. On the spur of the moment, this seemed to be the only method of securing a position of the new object, for upon bringing the slightest trace of the planet in the field the little point of light was instantly lost.

I got two sets of distances and one set of position angles, and then attempted to refer it to Jupiter but found that one of the wires of the micrometer was broken out and the other loose. Before anything could be done the object rapidly disappeared in the glare of Jupiter. From the fact that it was not left behind by the planet in its motion, I was convinced that the object was a satellite. A careful watch was kept at the preceding limb of the planet for the reappearance of the satellite, but up to day. light it could not be seen.

Though positive that a new satellite had been found, extreme caution suggested that it would be better to wait for a careful verification before making any announcement.

The following night with the 36 inch belonging to Professor Schaeberle, he kindly gave it up to me, and shortly before midnight the satellite was again detected rapidly leaving the planet on the following side. That morning I had put new wires in the micrometer, and now began a series of careful measures for position. As I have said, the satellite was so small that no trace of Jupiter could be admitted into the field for reference in the measures. It was necessary, therefore, to bisect the satellite, with the planet out of the field, and then by sliding the eye-piece bring the limb of Jupiter into view and bisect it. This method did not permit any measures from the polar limbs of Jupiter. Following the satellite thus, it was seen to recede from the planet to a distance of some $36^{\prime \prime}$ from the limb when it gradually became stationary. Remaining so for a while it began once more to approach the planet and rapidly disappeared in the glow near the limb. The measures, repeated as rapidly as possible, thoroughly covered the elongation, and gave the means of approximating to its period.

The following morning a telegram was sent out announcing the discovery.*) Subsequent observations have thoroughly confirmed the discovery.

On account of its extreme closeness to the planet it is difficult to say just what its magnitude is. Taking every. thing into account, I have provisionally assigned it as thirteenth magnitude. I hope to be able to settle definitely this question by observing some little star near Jupiter and then afterwards determining its magnitude when the planet has left it. Until this is settled, any estimate of the actual size of the satellite must be the merest guess, but it will probably be found to not exceed roo miles in diameter, and perhaps less than that.

After the first few observations I inserted a piece of smoked mica in the eye-piece, and using this as an occulting bar, the measures were made with ease and accuracy. Careful measures thus made from the polar limbs for the Jovicentric latitude of the satellite, show that its orbit lies sensibly in the plane of Jupiter's equator and that consequently the satellite is not a new addition to the Jovan family, since it would doubtless require ages for the orbit to be so adjusted if the object were a capture.

A sufficiently long interval has not yet elapsed to permit an accurate determination of the periodic time of the new satellite, but using three of the measured elongations and the known mass of Jupiter I have deduced the following approximations to the period, by the formula :

$$
P=p \sqrt{\frac{m}{M} \frac{R^{3}}{r^{3}}}
$$

where $m$ and $M$ are the masses of the Earth and Jupiter, and $p$ and $r$ the period and distance of our Moon, $R$ in the three cases being derived from the direct measures and having the following values:

*) Die Centralstelle erhielt das Telegramm erst am 13. Sept. $7^{\mathrm{h}}$ Abends. 


$$
\begin{aligned}
& \text { r } 1225^{\circ} \text { miles Periodic time }=I^{\mathrm{h}} 47^{\mathrm{m}}: 6 \\
& 11275^{\circ} \quad \text { I I } 52.3 \\
& \text { II } 2400 \text { II } 49.0
\end{aligned}
$$

Hence the mean of these, I $I^{\mathrm{h}} 49^{\mathrm{m}} \cdot 6$, will not be far from the truth, as it seems to satisfy the mass of Jupiter.

It will be thus seen that this new satellite makes two revolutions in one day, and that its periodic time about the planet is less than two hours longer than the axial rotation of Jupiter. Excepting the inner satellite of Mars it is the most rapidly revolving satellite known. When sufficient observations have been obtained it will afford a new and independent determination of the mass of Jupiter. Of course from what I have said in reference to the diffculty of the new satellite, it will be apparent that the most powerful telescopes in the world, only, will show it.

Mt. Hamilton 1892 Sept. 21 .

E. E. Barnard.

\section{Bemerkung zu Deichmüller}

\section{„Ueber die Vorausberechnung der Cometen-Helligkeiten" in A. N. 3123.}

Von A' Berberich.

Eine kleine Bemerkung zu Herrn Prof. Deichniüller's Aufsatz uber Cometen-Helligkeiten (A.N. 3123) zu machen, wird mir wohl gestattet sein. Zunächst habe ich die bezüglich der zwei Erscheinungen des Encke'schen Cometen von $\mathrm{r}_{32}$ und 1835 gemachten Bemerkungen als hinfällig zu bezeichnen, da die von Herrn Prof. Deichmüller (p. $3^{8}$ ) gegebene Correctur der Cometendistanzen am 28 . Juni 1832 richtig ist.

Die neue Formel des Herrn Prof. Deichmüller, welche nur die heliocentrischen Distanzen als massgebend betrachtet, genügt in der That den Helligkeitsangaben beim Encke'schen Cometen viel besser, als die gewöhnlich benutzte. Die Richtigkeit der letzteren war aber von mir selbst schon (A. N. $283^{6}$ p. 52 ) in Zweifel gezogen worden; doch glaubte ich nicht wagen zu dürfen, zu einer anderen Formel überzugehen, deren Begründung durch das vielfach mangelhafte Material mir zu schwierig und auch zu bedenklich erschien; etwas verändert ist die Sachlage nun allerdings durch den Nachweis des oben erwähnten Irrthums.

Dass die neue Formel allgemeine Gtiltigkeit besitzen sollte, scheint mir aber doch noch nicht festgestellt. Man milsste aus ihr folgern, dass der Cometendurchmesser mit der Annäherung an die Erde wachsen miisse, wogegen aber die Messungen, speciell beim Encke'schen Cometen sprechen. Ungünstige Umstände bei diesen Messungen lassen deren Werth zwar nicht als sehr hoch erscheinen, ganz negiren wird man sie aber auch nicht können, ohne zu neuen Hypothesen greifen zu müssen. Ferner sei daran erinnert, dass photometrische Beobachtungen, welche in den letzten Jahren angestellt worden sind (z. B. von Herm Professor

Berlin, Kgl. Recheninstitut, 1892 Oct. 13.
G. Müller in Potsdam) sich sehr gut mit der alten Formel vereinigen liessen: den Zahlenwerthen nach. Sodann ist wohl noch nicht vergessen, dass der Comet d'Arrest im Herbst $189^{\circ}$ erst entdeckt wurde, als seine günstigste Stellung und der Periheldurchgang bereits vorüber waren, im Widerspruch mit der alten sowohl als mit der neuen Formel.

Es wird schwerlich von irgend einer Seite angenommen werden, dass die verwickelten Helligkeitsverhältnisse bei den Cometen durch eine, und zwar eine einzige Formel darzustellen wären. Bei dem Encke'schen Cometen (und vielleicht bei allen denen, welche der Erde. sehr nahe kommen können) scheint die Formel des Herrn Prof. Deichmüller den Vorzug zu haben. Eine andere Formel wird man aber bej den so zu sagen »gewöhnlichen . und wieder eine andere bei den ganz grossen Cometen nöthig haben.

Meine Hypothese über den Zusammenhang der Helligkeit des Encke'schen Cometen mit der Sonnenfleckenperiode soll hiermit keineswegs vertheidigt werden. Sie war der Sammlung der Helligkeitsangaben in A. N. 2836 nur aus dem Grunde beigefügt worden, weil sich für sie eine einfache physikalische Erklärung darbot, die mit den sonst in der Astrophysik angenommenen Theorien nicht im Widerspruch steht. Die Schlussbemerkung am angegebenen Orte ging vorzüglich dahin, zu neuen genaueren Beobachtungen, namentlich der periodischen Cometen, anzuregen, „um für die Lichtentwickelung eine besser der $W$ ahrheit sich anschliessende Function $\mathrm{zu}$ finden, als die jetzt angewandte ist. \& Es wäre zu wünschen, dass die neue Behandlung der Frage durch Herrn Prof. Deichmüller denselben Zweck fördere.

\section{Beobachtungen des Cometen 1892... (Barnard Oct. 12).}

Telegramme an die Centralstelle.
16. Oct. $8^{\mathrm{h}} 34^{\mathrm{m}} \cdot \mathrm{O}$ M. Z. Wien
AR. app. $=294^{\circ} 55^{\prime} 42^{\prime \prime}$
PD. app. $=78^{\circ} 29^{\prime} 46^{\prime \prime}$ Weiss.*)
I8. Oct. 8 39.0 M. Z. Nizza
$=296357$
$=79 \quad 145^{2}$
Javelle. Perrotin.

\section{A. Berberich.}

*) Die Beobachtung wurde am 17. Oct. den Mitgliedern der Centralstelle telegraphisch mitgetheilt. $K r$. 